\title{
Review of the Main Factors Affecting the Flotation of Phosphate Ores
}

\author{
Manar Derhy ${ }^{1}$, Yassine Taha ${ }^{1, *} \mathbb{C}$, Rachid Hakkou ${ }^{1,2}$ and Mostafa Benzaazoua ${ }^{1,3}$ \\ 1 Mining Environment and Circular Economy (EMEC), Mohammed VI Polytechnic University, \\ Lot 660. Hay Moulay Rachid, Ben Guerir 43150, Morocco; manar.derhy@um6p.ma (M.D.); \\ r.hakkou@uca.ma (R.H.); mostafa.benzaazoua@uqat.ca (M.B.) \\ 2 IMED-Lab, Faculty of Science and Technology, Cadi Ayyad University (UCA), BP 549, \\ Marrakech 40000, Morocco \\ 3 Institut de Recherche en Mines et en Environnement, Université du Québec en Abitibi-Témiscamingue, \\ 445 Boulevard de l'Université, Rouyn-Noranda, QC J9X5E4, Canada \\ * Correspondence: yassine.taha@um6p.ma
}

Received: 10 November 2020; Accepted: 7 December 2020; Published: 10 December 2020

\begin{abstract}
The way to successfully upgrade a phosphate ore is based on the full understanding of its mineralogy, minerals surface properties, minerals distribution and liberation. The conception of a treatment process consists of choosing the proper operations with an adequate succession depending on the ore properties. Usually, froth flotation takes place in phosphate enrichment processes, since it is cheap, convenient, and well developed. Nevertheless, it is a complex technique as it depends on the mineral's superficial properties in aqueous solutions. Aspects such as wettability, surface charge, zeta potential, and the solubility of minerals play a basic role in defining the flotation conditions. These aspects range from the reagents type and dosage to the $\mathrm{pH}$ of the pulp. Other variables namely particles size, froth stability, and bubbles size play critical roles during the treatment, as well. The overall aim is to control the selectivity and recovery of the process. The following review is an attempt to add to previous works gathering phosphate froth flotation data. In that sense, the relevant parameters of phosphate ores flotation are discussed while focusing on apatite, calcite, dolomite, and quartz as main constituent minerals.
\end{abstract}

Keywords: sedimentary phosphate ore; igneous phosphate ore; mineral processing; froth flotation; surface charge; wettability; apatite; dolomite; calcite; quartz

\section{Introduction}

Phosphate ores are the only pronounced source of phosphorus. As a crucial component with high economic importance, phosphorus remains indispensable in the phosphoric acid industry, fertilizers, and elemental phosphorus production. The demand on phosphate has increased throughout the years. A total of 47 million tons $\mathrm{P}_{2} \mathrm{O}_{5}$ were consumed worldwide in 2019. This consumption is predicted to increase up to 50 million tons in 2023 [1]. As presented in Table 1, the worldwide leaders of phosphate mine production are China (110 million tons/y), Morocco (36 million tons), United States (23 million tons/y), and Russia (14 million tons/y). Countries such as Jordan, Saudi Arabia, Vietnam, Brazil, Egypt, Australia, and Senegal produce between 1 and 8 million tons/y. Phosphate mine production is expected to grow, especially in Jordan, Morocco, Saudi Arabia, and Senegal following projects expansions [1].

Conventionally, phosphate deposits are classified into five major categories: Marine sedimentary, igneous, metamorphic, weathering sedimentary, and biogenic [2]. Sedimentary deposits are predominant, providing $80 \%$ of the world's phosphate production. These deposit's grades range typically between $10 \%$ and $30 \% \mathrm{P}_{2} \mathrm{O}_{5}$ and can be upgraded to (30-35\%) $\mathrm{P}_{2} \mathrm{O}_{5}$. Morocco, China, 
Middle East, and United States host the biggest sedimentary deposits. Igneous deposits occur in Russia, Brazil, South Africa, Canada, and Finland with grades ranging between $4 \%$ and $15 \% \mathrm{P}_{2} \mathrm{O}_{5}$ and can be upgraded to (35-40\%) $\mathrm{P}_{2} \mathrm{O}_{5}[3,4]$. Phosphate ores can also be classified based on their major gangue minerals as: (i) Siliceous ores if associated with silica, (ii) clayey ores if containing aluminum silicates, (iii) calcareous ores of sedimentary origin if containing carbonates as the major impurities, (iv) phosphate ores rich in organic matter, (v) phosphate ores with multiple gangue minerals, and finally, (vi) igneous and metamorphic phosphate ores if containing sulfides, magnetite, carbonates, nepheline, etc.

According to their genesis and based on the phosphate cycle, phosphate minerals can be grouped as primary or secondary minerals. The primary minerals represent the original and replenishing source of phosphorus. They occur in carbonatite and alkaline igneous rocks. Altered or disintegrated and decomposed by natural agents, the primary minerals are transformed into secondary phosphate minerals [5]. Hence, the igneous phosphate ores can hold a variety of phosphate minerals, which are seldom found in the sedimentary ores and vice-versa. Furthermore, there are more than 200 known phosphate minerals. The apatite group is the most abundant ( $95 \%$ of the phosphorus existing in the earth's crust). Examples of phosphate minerals are listed in Table 2. The impurities existing in sedimentary ores are likely to differ from the ones found in igneous deposits. Upgrading a phosphate ore of any type (e.g., sedimentary, igneous, etc.) consists of increasing its $\mathrm{P}_{2} \mathrm{O}_{5}$ content and eliminating the gangue minerals (it must contain over $30 \% \mathrm{P}_{2} \mathrm{O}_{5}$, with a $\mathrm{CaO} / \mathrm{P}_{2} \mathrm{O}_{5}$ ratio lower than $1.6 \%$, $\mathrm{SiO}_{2}$ content less than $3 \%, \mathrm{MgO}$ content less than $1 \%, \mathrm{Fe}_{2} \mathrm{O}_{3}$ content less than 7\% [6,7]). The occurrence of impurities in the phosphate concentrate causes several complications and a frailty for phosphoric acid production, as presented in Table 3. Phosphate ore refinement is achieved by beneficiation processes, which depend on the characteristics of the treated ore (e.g., gangue minerals, particles size, hardness, etc.). Comminution and size separation, mineral separation, chemical and thermal techniques are the most common $[2,8]$.

Froth flotation is a mineral separation technique used industrially since the late 19th century. Starting in 1940s, it has been included in phosphate ores enrichment processes. Froth flotation is based on the specific physicochemical properties of minerals surfaces, precisely the hydrophobicity and hydrophilicity of both valuable and unwanted gangue minerals. Hydrophobicity can be a natural characteristic, but for most minerals, including phosphate minerals, the intervention of specific reagents is required to control the flotation behavior and achieve satisfactory separation results [9]. Phosphate flotation was initially conducted using soap, then it evolved throughout the years with the development of reagents and the improvement of process parameters. Flotation is dynamic, it is based on the interaction of multiple scientific fundamentals such as surface and colloid chemistry, physics, crystallography, etc. [10]. The performance of a flotation system is vulnerable to a range of variables. These variables are gathered into three categories: (i) Operational, e.g., mineralogy/surface properties, feed rate, particle size, pulp density, temperature, etc. (ii) chemical, e.g., collectors, frothers, activators, depressants, $\mathrm{pH}$ regulators, and (iii) hydrodynamic, e.g., flotation cell design, agitation, air flow, etc. Phosphate flotation can be direct, reverse, or a succession of direct/reverse stages depending on circumstances. Direct flotation consists of floating the phosphate minerals by inducing hydrophobic surface properties. The opposite is the case during reverse flotation where gangue minerals are floated. Choosing the type of flotation depends on: (i) The phosphate mineral's initial grade, (ii) the economics of the reagents used, and (iii) the performance of the adopted flotation.

Froth flotation has been used to enrich sedimentary phosphate ores with siliceous impurities. It has replaced calcination in treating calcareous phosphate ores. It is also commonly used for processing igneous phosphate ores with usually less complications compared to sedimentary ores. Yet, igneous phosphate ores still present complications, as a single ore might hold numerous impurities and various types of phosphate minerals with different floatabilities [11]. Phosphate sedimentary ores usually contain apatite as the value mineral, carbonates, silica, and clays as impurities. The anioniccationic flotation termed the "Crago technique" is the common method for upgrading siliceous 
phosphate ores. This is used to upgrade Florida phosphate ores. In this process, francolite is floated using a fatty acid/fuel oil mixture. The rougher concentrate is scrubbed using acid to renovate the particles surfaces. The remaining silica is then floated using an amine reagent [12]. For calcareous ores, separation by flotation of carbonates (calcite and dolomite) and phosphates is challenging since the two mineral groups share similar surface chemical properties. There are also colloidal phosphate ores, sedimentary ores containing, in general, a very small grain sized apatite (cryptocrystal). The beneficiation of these ores is challenging. It requires fine grinding and the use of selective reagents since apatite is incorporated with gangue minerals, forming "collophanite".

Table 1. Leading phosphate producers [13].

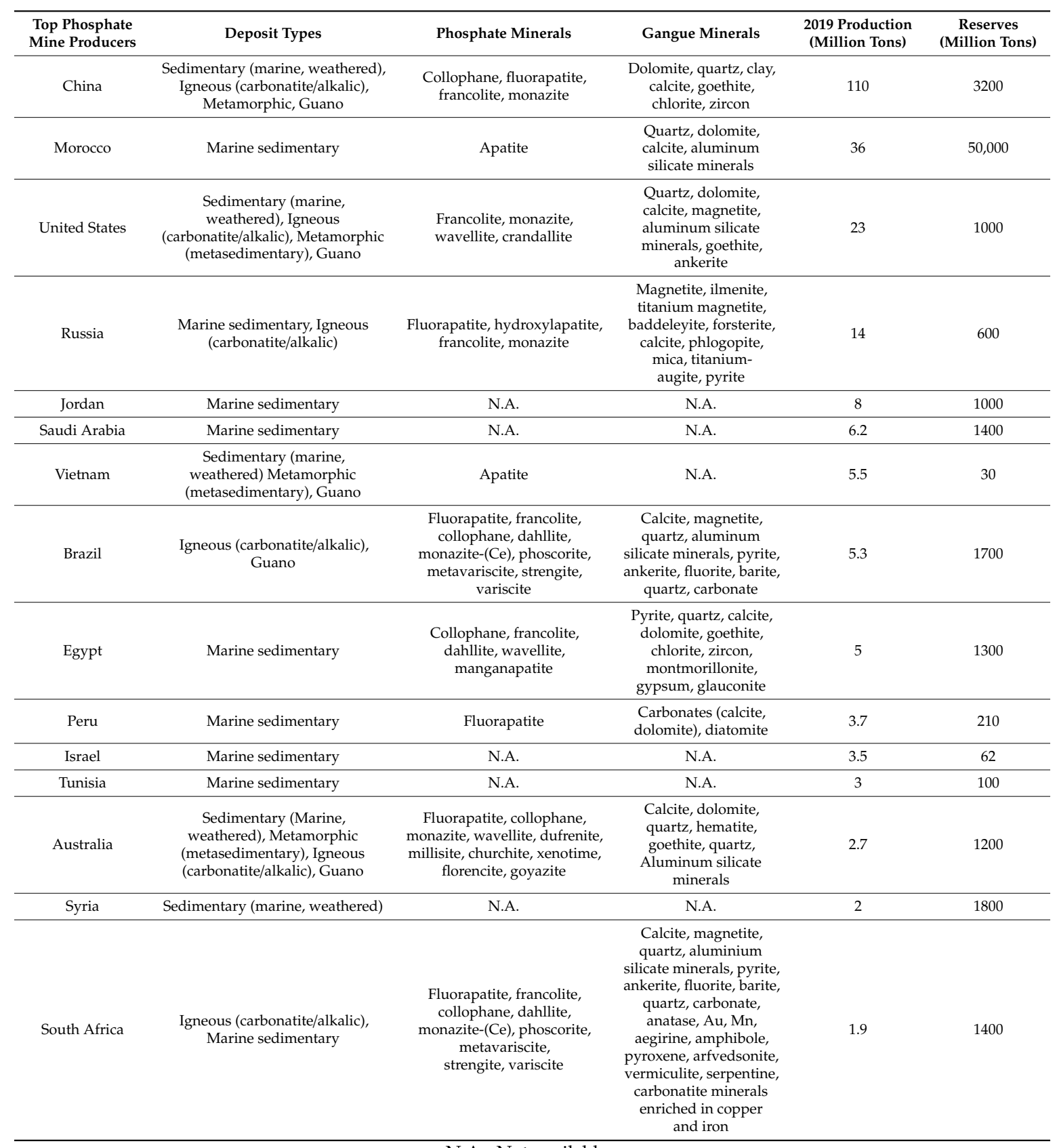


Table 2. Abundant phosphate minerals and their occurrence.

\begin{tabular}{|c|c|c|c|}
\hline Name & Types & Formula & Occurrence \\
\hline \multirow{4}{*}{ Apatite } & Chlorapatite & $\mathrm{Ca}_{5}\left(\mathrm{PO}_{4}\right)_{3} \mathrm{Cl}$ & $\mathrm{Ig}, \mathrm{Mt}$ \\
\hline & Hydroxylapatite & $\mathrm{Ca}_{5}\left(\mathrm{PO}_{4}\right)_{3} \mathrm{OH}$ & $\mathrm{Ig}, \mathrm{Mt}, \mathrm{Sd}$. \\
\hline & Fluorapatite & $\mathrm{Ca}_{5}\left(\mathrm{PO}_{4}\right)_{3} \mathrm{~F}$ & $\mathrm{Ig}, \mathrm{Mt}, \mathrm{Sd}$. \\
\hline & Francolite or Carbonate-fluorapatite & $\mathrm{Ca}_{5}\left(\mathrm{PO}_{4}, \mathrm{CO}_{3}\right)_{3}(\mathrm{~F}, \mathrm{O})$ & Sd, Mt. \\
\hline Xenotime & Xenotime-(Y) & $\mathrm{YPO}_{4}$ & Ig, Mt. (Phosphate minerals containing REE). \\
\hline Vivianite & & $\mathrm{Fe}_{3}\left(\mathrm{PO}_{4}\right)_{2} 8\left(\mathrm{H}_{2} \mathrm{O}\right)$ & $\begin{array}{l}\text { Ig, Mt, Sd. Occurs in organically rich } \\
\text { sedimentary deposits (clays and sandstones), } \\
\text { hydrothermal replacement deposits, and in } \\
\text { phosphate-rich granite pegmatites. }\end{array}$ \\
\hline Wavellite & & $\mathrm{Al}_{3}\left(\mathrm{PO}_{4}\right)_{2}(\mathrm{OH}, \mathrm{F})_{3} 5\left(\mathrm{H}_{2} \mathrm{O}\right)$ & $\begin{array}{l}\text { Sd, Mt. Occurs as a secondary mineral in } \\
\text { the oxidized low-grade metamorphic rocks, } \\
\text { epithermal veins, and in phosphate-rich } \\
\text { sedimentary deposits. }\end{array}$ \\
\hline Monetite & & $\mathrm{CaHPO}_{4}$ & $\begin{array}{l}\mathrm{Ig}, \mathrm{Sd} \text {. Occurs as coatings and cements in } \\
\text { guano rocks and as coatings on phosphate } \\
\text { minerals in granite pegmatite. }\end{array}$ \\
\hline Whitlockite & & $\mathrm{Ca}_{9} \mathrm{Mg}\left(\mathrm{PO}_{4}\right)_{6}\left(\mathrm{HPO}_{4}\right)$ & $\begin{array}{l}\text { Sd, Mt. Occurs in granite pegmatites; may be } \\
\text { formed in caves from leached guano. }\end{array}$ \\
\hline Brushite & & $\mathrm{Ca}\left(\mathrm{HPO}_{4}\right) 2 \mathrm{H}_{2} \mathrm{O}$ & Sd. Occurs in cave guano deposits. \\
\hline
\end{tabular}

Ig: Igneous rocks; Sd: Sedimentary rocks; Mt: Metamorphic rocks.

Table 3. Potential effects of phosphate impurities and their acceptable levels.

\begin{tabular}{|c|c|c|c|c|}
\hline Impurity & Potential Sources & Acceptable Level & Desirable Properties & Undesirable Properties \\
\hline $\mathrm{Al}_{2} \mathrm{O}_{3}$ & $\begin{array}{l}\text { Aluminum silicate minerals, } \\
\text { wavellite, metavariscite, } \\
\text { crandallite, variscite. }\end{array}$ & Up to $3 \%[7,14]$ & $\begin{array}{l}\text { Low } \mathrm{Al}_{2} \mathrm{O}_{3} \text { content improves } \\
\text { the filtration rate by promoting } \\
\text { the growth of gypsum crystals } \\
\text { [15]. Reduces corrosion caused } \\
\text { by fluoride ion [14]. }\end{array}$ & $\begin{array}{c}\text { High } \mathrm{Al}_{2} \mathrm{O}_{3} \text { content impairs } \\
\text { filtration, increases acid } \\
\text { viscosity [14], decreases plant } \\
\text { capacity, and } \mathrm{P}_{2} \mathrm{O}_{5} \text { recovery [7]. }\end{array}$ \\
\hline $\mathrm{Fe}_{2} \mathrm{O}_{3}$ & $\begin{array}{l}\text { Goethite, magnetite, } \\
\text { hematite, strengite. }\end{array}$ & Up to $2 \%[14]$ & $\begin{array}{l}\text { Recoverable in case of excessive } \\
\text { presence [14]. }\end{array}$ & $\begin{array}{l}\text { High } \mathrm{Fe}_{2} \mathrm{O}_{3} \text { content causes } \\
\text { excessive sludge formation, } \\
\text { decreases the filtration rate, } \\
\text { and influences the acid } \\
\text { viscosity [14]. }\end{array}$ \\
\hline $\mathrm{MgO}$ & Dolomite, ankerite, phoscorite. & Less than $1 \%[7]$ & May have a nutrient value [14]. & $\begin{array}{l}\text { Increases the sulfuric acid } \\
\text { consumption and impairs } \\
\text { gypsum filtration [7]. }\end{array}$ \\
\hline Fluorine & Fluorite, fluorapatite, francolite. & Up to $4 \%[14]$ & $\begin{array}{l}\text { Can be recovered as a } \\
\text { by-product [14]. }\end{array}$ & $\begin{array}{l}\text { Causes corrosion, mud, slurry } \\
\text { formation, and might impair } \\
\text { gypsum filtration [15]. }\end{array}$ \\
\hline Chlorine & Chlorapatite. & $\begin{array}{l}\text { Less than } 0.03 \% \\
\text { (stainless steel } \\
\text { equipment) }\end{array}$ & None. & Increases equipment erosion [7]. \\
\hline $\mathrm{CaO}$ & $\begin{array}{l}\text { Calcite, dolomite, ankerite, } \\
\text { fluorite, gypsum, } \\
\text { crandallite, apatite. }\end{array}$ & $\begin{array}{c}\mathrm{CaO}: \mathrm{P}_{2} \mathrm{O}_{5} \text { ratio less } \\
\text { than } 1.6[7]\end{array}$ & $\begin{array}{l}\text { Improves the reactivity of the } \\
\text { phosphate ore [15]. }\end{array}$ & $\begin{array}{l}\text { Increases the consumption of } \\
\text { sulfuric acid and causes foam } \\
\text { formation during the acid } \\
\text { attack [15]. }\end{array}$ \\
\hline
\end{tabular}


Table 3. Cont.

\begin{tabular}{|c|c|c|c|c|}
\hline Impurity & Potential Sources & Acceptable Level & Desirable Properties & Undesirable Properties \\
\hline Cadmium & $\begin{array}{l}\text { Carbonate apatite (Cd } \\
\text { substitutes Ca and/or is trapped } \\
\text { in the structure during its } \\
\text { formation by the sedimentation } \\
\text { of phosphate rock) [16]. }\end{array}$ & $\begin{array}{l}\mathrm{Up} \text { to } 60 \mathrm{mg} / \mathrm{kg} \mathrm{P} \mathrm{P}_{2} \mathrm{O}_{5} \\
\text { (European union) [17] }\end{array}$ & None. & $\begin{array}{l}\text { Does not pose notable problems } \\
\text { in the production of phosphoric } \\
\text { acid [7]. Toxic in specific end } \\
\text { products (animal feed and } \\
\text { fertilizers) [15]. }\end{array}$ \\
\hline Uranium & $\begin{array}{l}\text { Following the sedimentation of } \\
\text { the phosphate ore, U might } \\
\text { substitute Ca in the apatite } \\
\text { crystal and/or is adsorbed into it } \\
\text { or forms uranium phosphate } \\
\text { minerals such as } \\
\text { phosphuranylite [18]. }\end{array}$ & $\begin{array}{l}\text { Typically, } 4 \mathrm{~Bq} \mathrm{U} \text { per } \\
\qquad \mathrm{g} \mathrm{P}_{2} \mathrm{O}_{5}\end{array}$ & $\begin{array}{l}\text { Can be recovered as } \\
\text { a by-product [14]. }\end{array}$ & Hazardous to human health [7]. \\
\hline
\end{tabular}

With the depletion of rich phosphate deposits of simple compositions and the abundance of complex poor phosphate reserves, research in phosphate froth flotation keeps evolving. At this stage, efforts are directed toward understanding what affects phosphate flotation and the different aspects that result in the success or the failure of a flotation operation. With these regards, the aim of this review is to focus on the factors affecting the flotation of sedimentary phosphate ores, as they provide $80 \%$ of the world's phosphate production.

\section{Parameters Affecting Phosphate Flotation}

\subsection{Phosphate and Gangue Minerals' Surface Properties}

Mineral surface properties are critical for flotation control as they represent the fundamental concepts behind the technological process. They allow to, both, predict and describe the physical and chemical superficial interactions of the mineral-reagent, mineral-medium, and mineral-mineral interactions.

\subsubsection{Phosphate Minerals' Solubility and Surface Charge}

The surface charge of phosphate minerals and their impurities (i.e., gangue minerals) is affected by many variables, e.g., $\mathrm{pH}$ and $\mathrm{RPO}$ values (reduction/oxidation potential). Respectively, the mechanisms governing the surface charge are complex rendering separation by froth flotation challenging in some cases. Minerals from the apatite group are the most abundant. It has been suggested that their active surface sites are formed by calcium hydroxyl $(\equiv \mathrm{CaOH})$ and phosphorus hydroxyl $(\equiv \mathrm{POH})$ groups [19]. It is considered that $\equiv \mathrm{Ca}-\mathrm{OH}^{2+}$ and $\equiv \mathrm{P}-\mathrm{O}^{-}$are dominant surface groups [19]. The ions $\mathrm{H}^{+}$and $\mathrm{OH}^{-}$are specifically adsorbed on the surface. Basically, depending on the $\mathrm{pH}$, two different surface groups (both metal ions and ligands) can be adsorbed on the hydroxylated apatite surface. Hence, the adsorption of the flotation modifying agents on mineral surfaces is usually expressed in relation to $\mathrm{pH}$ being a critical parameter. The apatite's surface charge depends not only on $\mathrm{pH}$ but also on the concentration of various chemical species as well as on pretreatments. In this context, hydrogen, hydroxyl, calcium, fluoride, and phosphate are the apatite's potential determining ions [20]:

- $\mathrm{H}^{+}$and $\mathrm{OH}^{-}$ions are critical as they control the solution $\mathrm{pH}$ and eventually the mineral's surface charge [19];

- $\quad$ Phosphate $\left(\mathrm{PO}_{4}{ }^{3-}\right)$ decreases the mineral's surface charge under all $\mathrm{pH}$ conditions [20];

- Calcium makes the mineral more positively charged under all pH conditions [20];

- Fluoride is found to increase the surface charge in acidic medium and slightly decreases it in basic solutions following the possible formation of fluorite $\left(\mathrm{CaF}_{2}\right)$ and fluorapatite $\left(\mathrm{Ca}_{5}\left(\mathrm{PO}_{4}\right)_{3} \mathrm{~F}\right)$, respectively [20].

The zeta potential expresses the electrical potential difference between the ion layer adsorbed onto the particle's surface and the bulk solution [21]. It enables prediction as to whether or not a reagent will bind to the particle's surface. The isoelectric point (IEP) is the $\mathrm{pH}$ value corresponding to a zero zeta potential. IEP values of hydroxyapatite, fluorapatite, francolite, and collophane in 
different operating conditions are listed in Table 4. Parameters such as mineral purity, particles size, solid content, electrolyte, and measurement technique influence the IEP value.

\subsubsection{Gangue Minerals' Solubility and Surface Charge}

The most common impurities found in the sedimentary phosphate ores are carbonates (calcite and dolomite) and quartz.

- Calcite solubility and surface charge

Calcite solubility in aqueous medium leads to the release or deposition of $\mathrm{Ca}^{2+}$ and $\mathrm{CO}_{3}{ }^{2-}$ on mineral surfaces depending on the solution $\mathrm{pH}$. This latter and concentrations of $\mathrm{Ca}^{2+}, \mathrm{CO}_{3}{ }^{2-}$, and $\mathrm{HCO}_{3}$ might fluctuate under the influence of dissolved atmospheric $\mathrm{CO}_{2}$. Moreover, the hydrated calcite surface can have both protonated anion sites $\left(>\mathrm{CO}_{3} \mathrm{H}\right)$ and hydroxylated cation sites $(>\mathrm{CaOH})$. Hence, in a froth flotation system, the solution $\mathrm{pH}$ controls the calcite surface charge. Nevertheless, it has been demonstrated experimentally that, when the calcium ions concentration was kept constant, the calcite surface charge was independent of $\mathrm{pH}$ [22]. The adsorption of $\mathrm{Ca}^{2+}$ and $\mathrm{CO}_{3}{ }^{2-}$ onto the mineral surface (Figure 1) is represented through the following surface complexation Reactions (with or without the presence of $\mathrm{CO}_{2}$ ) [22].

$$
\begin{gathered}
>\mathrm{CO}_{3} \mathrm{H}+\mathrm{Ca}^{2+} \rightarrow>\mathrm{CO}_{3} \mathrm{Ca}^{+}+\mathrm{H}^{+} \\
>\mathrm{CaOH}+\mathrm{CO}_{2} \rightarrow>\mathrm{CaCO}_{3}^{-}+\mathrm{H}^{+} \\
>\mathrm{CaOH}+\mathrm{CO}_{2} \rightarrow>\mathrm{CaHCO}_{3}
\end{gathered}
$$

Table 4. The isoelectric point (IEP) values of phosphate minerals and their measurement operating conditions.

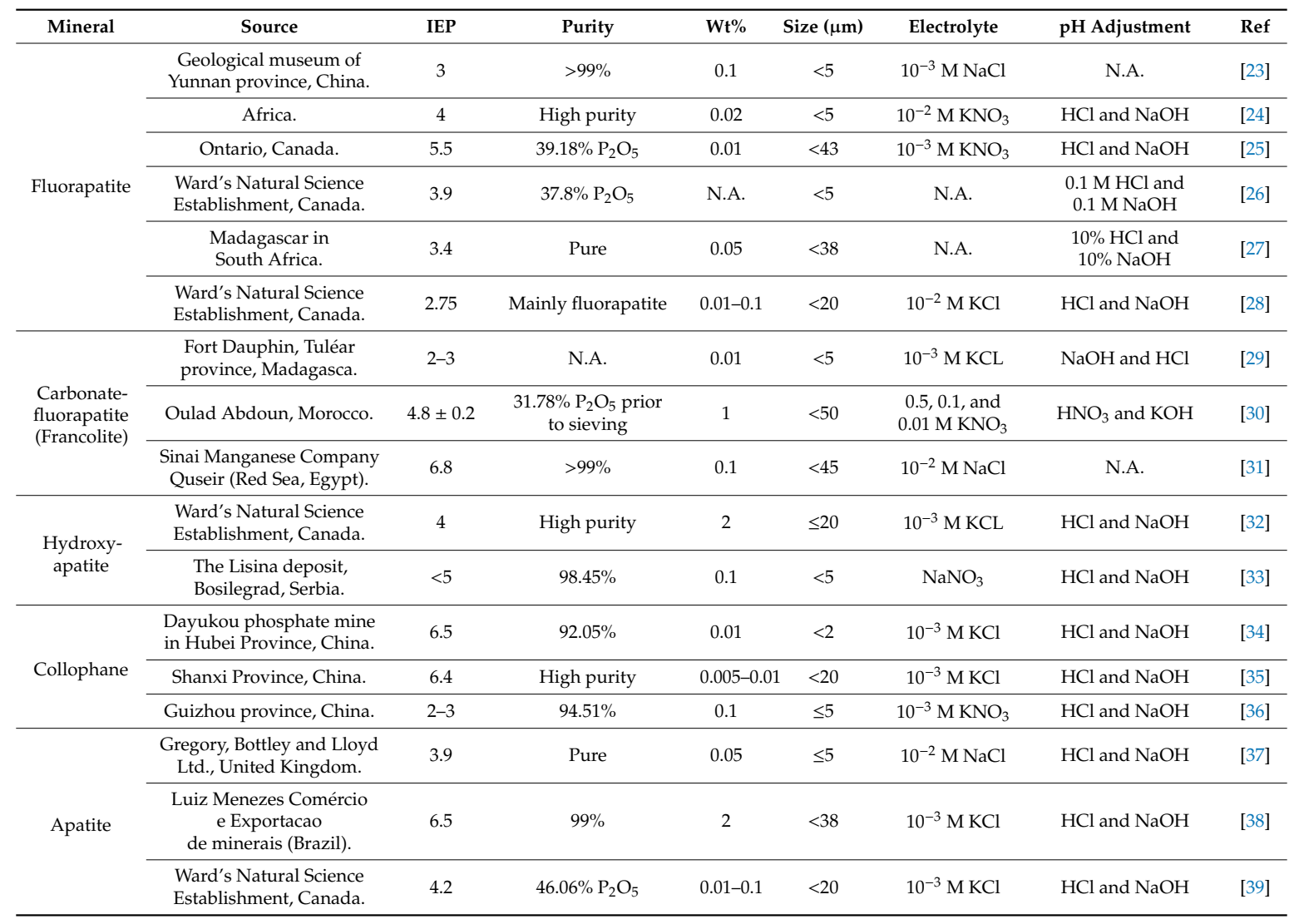




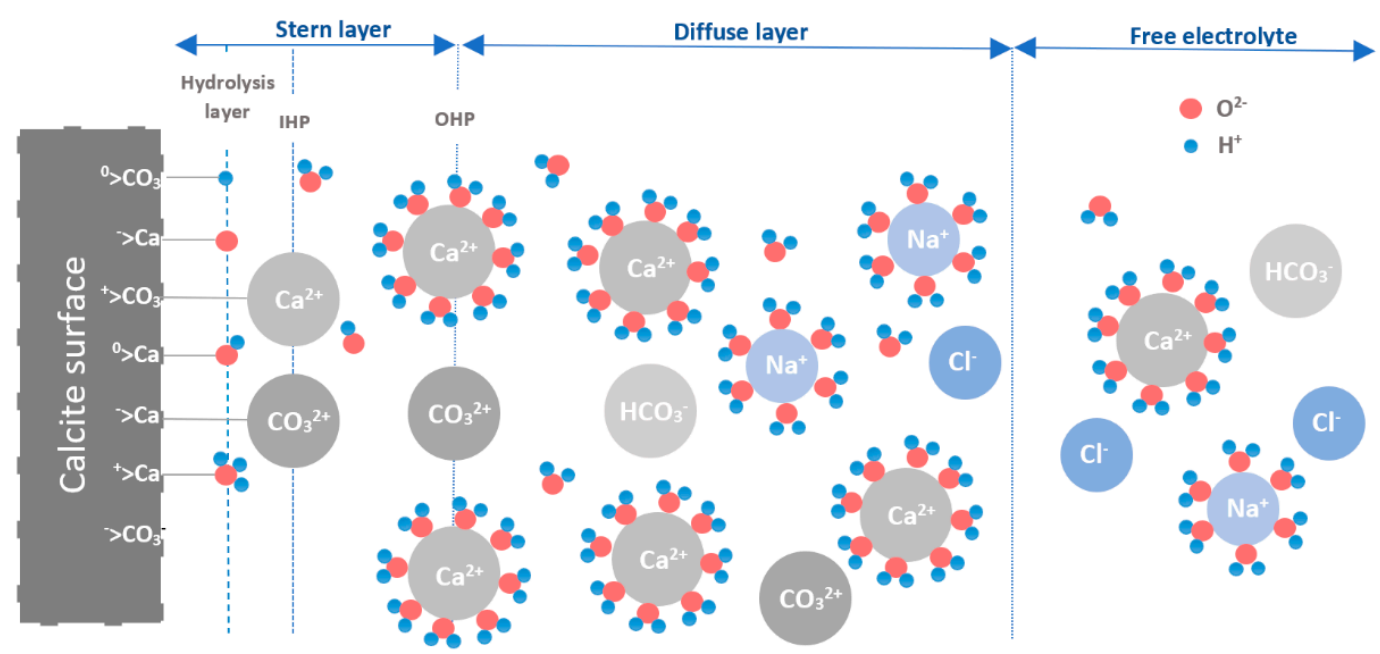

Figure 1. Illustration of the electrical double layer of calcite surface in water with $\mathrm{NaCl}$ as the electrolyte. IHP and OHP stand for the inner and outer Helmholtz planes, respectively [22].

To summarize, calcite surface determining ions (PDI) are the lattice ions $\mathrm{Ca}^{2+}$ and $\mathrm{CO}_{3}{ }^{2-} \cdot \mathrm{Mg}^{2+}$ can also be considered as a PDI. The $\mathrm{pH}$ affects the zeta potential by moderating the equilibrium $\mathrm{pCa}$ for a given $\mathrm{CO}_{2}$ partial pressure $\left(\mathrm{pCO}_{2}\right)$, therefore, it does not directly control the zeta potential [22]. Table 5 presents calcite IEP values and their measurement operating conditions.

Table 5. IEP calcite values and their measurement operating conditions.

\begin{tabular}{cccccccc}
\hline Source & IEP & Purity & Wt $(\%)$ & Size $(\mu \mathrm{m})$ & Electrolyte & pH Adjustment & Ref \\
\hline $\begin{array}{c}\text { Rongan mine in Guangxi } \\
\text { province, China. }\end{array}$ & 9.2 & $99.21 \% \mathrm{CaO}$ & 0.1 & $<5$ & $10^{-3} \mathrm{M} \mathrm{KCl}$ & $\mathrm{HCl}$ and NaOH & {$[40]$} \\
\hline $\begin{array}{c}\text { Guangxi province and } \\
\text { Hunan province, China. }\end{array}$ & 9.5 & $98.91 \%$ & 0.1 & $<2$ & $10^{-2} \mathrm{M} \mathrm{KNO}_{3}$ & $\mathrm{HCl}$ and NaOH & {$[41]$} \\
\hline Yunna province of China. & 9.5 & $98 \%$ & 0.01 & $<5$ & $10^{-3} \mathrm{M} \mathrm{KCl}$ & $\mathrm{HCl}$ and NaOH & {$[42]$} \\
\hline $\begin{array}{c}\text { Shizhuyuan mine, } \\
\text { Chenzhou, China. }\end{array}$ & 10.3 & $>98 \%$ & 0.05 & $<2$ & $10^{-2} \mathrm{M} \mathrm{KCl}$ & $\mathrm{HCl}$ and NaOH & {$[43]$} \\
\hline
\end{tabular}

- Dolomite solubility and surface charge

The surface of dolomite resembles that of calcite. Dolomite is soluble in aqueous medium and the lattice ions $\mathrm{Ca}^{2+}, \mathrm{Mg}^{2+}$, and $\mathrm{CO}_{3}{ }^{2-}$ are susceptible, depending on the solution $\mathrm{pH}$, to either dissolve in the solution or precipitate on mineral surfaces. Moreover, the solution $\mathrm{pH}$ and concentrations of $\mathrm{Ca}^{2+}, \mathrm{Mg}^{2+}, \mathrm{CO}_{3}{ }^{2-}$, and $\mathrm{HCO}_{3}$ might fluctuate under the influence of dissolved atmospheric $\mathrm{CO}_{2}$. The species existing on the dolomite surface were investigated by some researchers. Figure 2 presents the calculated speciation at the dolomite-solution interface [44]. Based on these calculations, at a $\mathrm{pH}$ below 4 , carbonate sites are protonated with predominantly $>\mathrm{CO}_{3} \mathrm{H}$ species. In higher $\mathrm{pH}$ conditions, $>\mathrm{CO}^{3-}$ dominates as deprotonation occurs. $\mathrm{pH}$ as well as the dissolved carbonate concentration influence the speciation at the dolomite metal sites. At a pH below $8,>\mathrm{MeOH}^{2+}$ species are dominant, however, once the $\mathrm{pH}$ exceeds $8>\mathrm{MeCO}^{3-}$ dominates. The study confirms the similarities between calcite and dolomite interfaces in aqueous solutions. It also indicates that the PDI for the dolomite surface are its lattice ions (as for calcite) being $\mathrm{Ca}^{2+}, \mathrm{Mg}^{2+}$, and $\mathrm{CO}_{3}{ }^{2-}$ [44]. Table 6 presents IEP values of dolomite and their measurement conditions. 


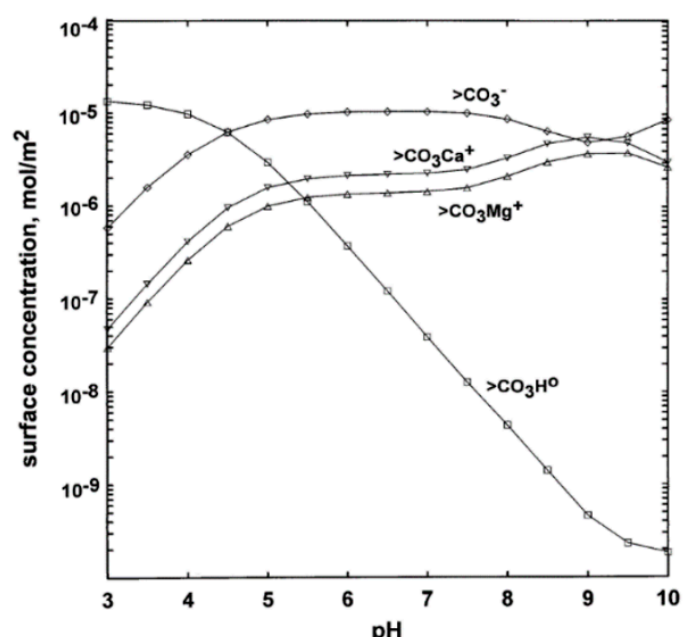

(a)

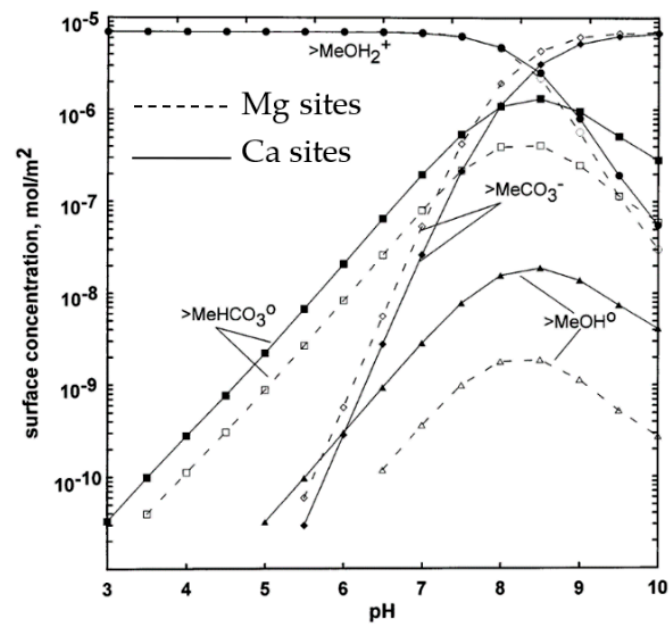

(b)

Figure 2. Calculated surface speciation of dolomite $\left(0.01 \mathrm{~mol} / \mathrm{L} \mathrm{NaCl}, 10^{-3} \mathrm{M} \mathrm{Ca}^{2+}\right.$, and $\mathrm{Mg}^{2+}$ solution in equilibrium with $\mathrm{pCO}_{2}=10^{-3.5} \mathrm{~atm}$ ). (a) Carbonate sites, and (b) metal sites [44].

Table 6. IEP values of dolomite and their measurement conditions.

\begin{tabular}{cccccccc}
\hline Source & IEP & Purity & Wt (\%) & Size $(\mu \mathrm{m})$ & Electrolyte & pH Adjustment & Ref \\
\hline $\begin{array}{c}\text { Wulongquan Mine in } \\
\text { Hubei Province, China. }\end{array}$ & 4.4 & $90.62 \%$ & 0.01 & $<2$ & $10^{-3} \mathrm{M} \mathrm{KCl}$ & $\mathrm{HCl}$ and NaOH & {$[34]$} \\
\hline $\begin{array}{c}\text { Sterling Hill Mine, New } \\
\text { Jersey, USA. }\end{array}$ & 4.8 & relatively pure & 0.01 & $\mathrm{D} 50<2.3$ & $10^{-3} \mathrm{M} \mathrm{NaCl}$ & $\mathrm{HCl}$ and $\mathrm{KOH}$ & {$[45]$} \\
\hline $\begin{array}{c}\text { Ward's Natural Science } \\
\text { Establishment, Canada. }\end{array}$ & 3.37 & mainly dolomite & $0.01-0.1$ & $<20$ & $10^{-2} \mathrm{M} \mathrm{KCl}$ & $\mathrm{HCl}$ and KOH & {$[28]$} \\
\hline $\begin{array}{c}\text { Ward's Natural Science } \\
\text { Establishment, Canada. }\end{array}$ & 6.2 & $\begin{array}{c}36.06 \% \mathrm{MgO}, \\
60.27 \% \mathrm{CaO}\end{array}$ & $0.01-0.1$ & $<20$ & $10^{-3} \mathrm{M} \mathrm{KCl}$ & $\mathrm{HCl}$ and NaOH & {$[39]$} \\
\hline $\begin{array}{c}20.62 \% \mathrm{MgO}, \\
\text { Selasvann, Norway. }\end{array}$ & $71.36 \% \mathrm{CaO}$ & 0.01 & $<43$ & $10^{-3} \mathrm{M} \mathrm{KNO}$ & $\mathrm{HCl}$ and NaOH & {$[25]$} \\
\hline $\begin{array}{c}\text { Sinai Manganese } \\
\text { Company Quseir, } \\
\text { Red Sea, Egypt. }\end{array}$ & 8.5 & $>99 \%$ & 0.1 & $<45$ & $10^{-2} \mathrm{M} \mathrm{NaCl}$ & N.A. & {$[31]$} \\
\hline
\end{tabular}

- Quartz solubility and surface charge

Quartz can be found as an impurity in most phosphate ores. Its superficial properties in aqueous solution resembles the properties of amorphous silica. Therefore, the two materials carry similar functional surface groups, and consequently, have the same reaction mechanism [46]. In the quartz-fatty acid flotation system, and in the absence of metal ions, the predicted Reactions are:

$$
\begin{gathered}
>\mathrm{SiOH} \rightarrow \mathrm{SiO}^{-}+\mathrm{H}^{+}, \\
\text {and } \mathrm{RCOOH} \rightarrow \mathrm{RCOO}^{-}+\mathrm{H}^{+} .
\end{gathered}
$$

According to the reactions above, the adsorption of fatty acids on the quartz surface is nearly impossible. Though, in the presence of metal ions, quartz hydrophobicity can be achieved by surface reactions such as the ones presented below (Reaction 6, 7, and 8) [46]. Table 7 presents the IEP values of quartz and its measurement operating conditions.

$$
\begin{gathered}
>\mathrm{SiOH}+\mathrm{Me}^{2+} \rightarrow \mathrm{SiOMe}^{+}+\mathrm{H}^{+}, \\
>\mathrm{SiOH}+\mathrm{Me}^{2+}+\mathrm{RCOO}^{-}+\mathrm{H}_{2} \mathrm{O} \rightarrow \mathrm{SiOMeOHRCOO}^{-}+2 \mathrm{H}^{+}, \\
\text {Or, }>\mathrm{SiOH}+\mathrm{Me}^{+}+\mathrm{RCOO}^{-}+\mathrm{H}_{2} \mathrm{O} \rightarrow \underset{>}{>\mathrm{SiOH}} \mathrm{SiOH}^{\mathrm{SiOH}} \mathrm{MeHRCOO}^{-}+3 \mathrm{H}^{+} .
\end{gathered}
$$


Table 7. IEP values of quartz and measurement conditions.

\begin{tabular}{cccccccc}
\hline Source & IEP & Purity & Wt (\%) & Size $(\mu \mathrm{m})$ & Electrolyte & pH Adjustment & Ref \\
\hline $\begin{array}{c}\text { Ward's Natural Science } \\
\text { Establishment, Canada. }\end{array}$ & Negative & $96.02 \%$ & $0.01-0.1$ & $<20$ & $10^{-3} \mathrm{M} \mathrm{KCl}$ & $\mathrm{HCl}$ and NaOH & {$[39]$} \\
\hline SAC Co., South Korea. & 2.1 & $99.2 \% \mathrm{SiO}_{2}$ & N.A. & $<5$ & N.A. & $\begin{array}{c}0.1 \mathrm{M} \mathrm{HCl} \mathrm{and} \\
0.1 \mathrm{M} \mathrm{NaOH}\end{array}$ & {$[26]$} \\
\hline Hubei province, China. & 2 & Relatively pure & 0.05 & $<38$ & N.A. & $\begin{array}{c}10 \% \mathrm{HCl} \text { and } \\
10 \% \mathrm{NaOH}\end{array}$ & {$[27]$} \\
\hline $\begin{array}{c}\text { Luanping county, } \\
\text { Hebei province, China. }\end{array}$ & 2 & $99 \%$ & 0.05 & $<5$ & N.A. & $\mathrm{HCl}$ and NaOH & {$[47]$} \\
\hline
\end{tabular}

\subsubsection{Wettability (Contact Angle)}

Mineral wettability is critical to the establishment of an efficient froth flotation process. It conveys the mineral's floatability with or without the addition of collectors. The wettability is expressed by an empirical angle. It can be experimentally measured by various methods. For instance, a liquid drop is laid on a solid surface. The intersection of the liquid-solid and liquid-vapor interfaces forms the angle termed "contact angle". A hydrophobic surface retains a contact angle larger than $90^{\circ}$. A hydrophilic surface has a smaller contact angle [48]. The contact angle was first introduced by Tomas Young (1805) and can be calculated through its equation:

$$
\gamma_{\mathrm{lv}} \cos \theta_{\mathrm{Y}}=\gamma_{\mathrm{sv}}-\gamma_{\mathrm{sl}}
$$

where $\gamma_{\mathrm{lv}}, \gamma_{\mathrm{sv}}$, and $\gamma_{\mathrm{sl}}$ represent the liquid-vapor, solid-vapor, and solid-liquid interfacial tensions, respectively, and $\theta_{\mathrm{Y}}$ is the Young's contact angle.

However, the contact angles calculated through young's equation are usually different from the measured ones. The calculated $\theta_{Y}$ can be experimentally confirmed only in ideal conditions where the solid surface is physically and chemically homogenous, and the experiment is conducted under extremely controlled conditions. In reality, most measurements are done on heterogenous imperfect solid surfaces (especially for minerals). The advancing and the receding contact angles are other variations of $\theta$. They are measured by expanding and contracting the liquid, respectively and the difference between these two is called the hysteresis $(\mathrm{H})$, a very interesting and informative parameter:

$$
\mathrm{H}=\theta_{\mathrm{a}}-\theta_{\mathrm{r}} .
$$

Table 8 presents phosphate minerals, calcite, dolomite, and quartz contact angles with water using different experimental methods. As already mentioned, the contact angle's precision depends on the sample preparation as its interface needs to be smooth and homogeneous and the measurement must be conducted in controlled conditions to avoid vibrations. 
Table 8. Contact angle values of phosphate minerals, calcite, dolomite, quartz, and their measurement conditions.

\begin{tabular}{|c|c|c|c|c|c|c|c|}
\hline \multicolumn{2}{|c|}{ Mineral } & Source & The Contact Angle Type & Method & \multicolumn{2}{|c|}{ Contact Angle Value In $^{\circ}$} & Ref \\
\hline \multirow{9}{*}{ Fluorapatite } & \multirow{6}{*}{ Single crystal } & Ontario, Canada. & - & The captive bubble & 36 & & [49] \\
\hline & & \multirow{4}{*}{$\begin{array}{l}\text { Anemzy, Imilchil, High Atlas } \\
\text { Mts, Morocco. }\end{array}$} & \multirow{4}{*}{ Static } & \multirow{4}{*}{ The sessile drop } & $(001)$ & 45.1 & \multirow{4}{*}[50]{} \\
\hline & & & & & $(100)$ & 58.9 & \\
\hline & & & & & $(101)$ & 63.6 & \\
\hline & & & & & $(111)$ & 72.8 & \\
\hline & & Yunnan and Hunan Province, China. & Static & The sessile drop & 54 & & [51] \\
\hline & \multirow{3}{*}{ Mineral powder } & \multirow{3}{*}{ Gregory, Bottley and Lloyd, London. } & \multirow{3}{*}{-} & \multirow{3}{*}{$\begin{array}{l}\text { Capillary penetration } \\
\text { (Washburn method) }\end{array}$} & $-425+150 \mu \mathrm{m}$ & 52.7 & \multirow{3}{*}{52} \\
\hline & & & & & $-150+38 \mu \mathrm{m}$ & 8.35 & \\
\hline & & & & & $-38 \mu \mathrm{m}$ & 55.3 & \\
\hline \multirow{3}{*}{ Carbonate fluorapatite } & White pebbles & \multirow{3}{*}{ Central Florida, USA. } & \multirow{3}{*}{ Advancing } & \multirow{3}{*}{ The sessile drop } & \multicolumn{2}{|c|}{0} & \multirow{3}{*}{53} \\
\hline & Tan pebbles & & & & 10 & & \\
\hline & Black pebbles & & & & 10 & & \\
\hline Collophane & Mineral powder & $\begin{array}{l}\text { Phosphate mine in Guizhou } \\
\text { province, China. }\end{array}$ & - & $\begin{array}{l}\text { Capillary penetration } \\
\text { (Washburn method) }\end{array}$ & Abou & & [36] \\
\hline \multirow{2}{*}{ Calcite } & $\begin{array}{l}\text { Calcite crystals } \\
\text { (Iceland Spar) }\end{array}$ & $\begin{array}{l}\text { Ward's Natural Science } \\
\text { Establishment, USA. }\end{array}$ & Advancing & The sessile drop & 21 & & [54] \\
\hline & Single crystal & Yunnan and Hunan Province, China. & Static & The sessile drop & 45 & & [51] \\
\hline \multirow{3}{*}{\multicolumn{2}{|c|}{ Dolomite }} & Selasvann, Norway. & - & $\begin{array}{c}\text { The captive } \\
\text { bubble technique }\end{array}$ & 50 & & [49] \\
\hline & & Haicheng of Liaoning Province, China. & - & - & 11. & & {$[55]$} \\
\hline & & Konya-Argit region, in Turkey. & - & $\begin{array}{c}\text { The captive } \\
\text { bubble technique }\end{array}$ & Between 5.6 & d 7.68 & [56] \\
\hline \multirow{3}{*}{ Quatrz } & \multirow[t]{2}{*}{ Hand-picked } & $\begin{array}{l}\text { Xinjiang Keketuohai Rare Metal } \\
\text { Mine, China. }\end{array}$ & Advancing & The sessile drop & \multicolumn{2}{|c|}{ Between 1.5 and 5} & [57] \\
\hline & & $\begin{array}{l}\text { Anqian iron mine, Liaoning } \\
\text { Province, China. }\end{array}$ & Static & Sessile drop method & \multicolumn{2}{|c|}{ Between 22 and 25} & [58] \\
\hline & Mineral powder & $\begin{array}{l}\text { Phosphate mine in Guizhou } \\
\text { province, China. }\end{array}$ & - & $\begin{array}{l}\text { Capillary penetration } \\
\text { (Washburn method) }\end{array}$ & \multicolumn{2}{|c|}{ About $20^{\circ}$} & [36] \\
\hline
\end{tabular}




\subsection{Flotation Reagents}

Flotation reagents, especially regulators (activators, depressants, and $\mathrm{pH}$ regulators) and collectors, impact the selective separation of phosphate minerals from impurities, which are usually carbonates (calcite and dolomite) and silicates (quartz). During the phosphate direct flotation process, gangue minerals are depressed and the phosphate mineral retaining a hydrophobic surface is floated. The opposite occurs during reverse flotation. Table 9 summarizes the reagents used in the phosphate reverse and direct flotation.

\subsubsection{Gangue Minerals Reagents}

- $\quad$ Calcite and Dolomite Reagents

Generally, anionic collectors are used for carbonates flotation. In the past decades and still in some cases today, anionic collectors' production depended on tall oil and oxidized petroleum as raw materials. However, these come with multiple downsides. Rather, vegetable oils such as rice bran, hydrogenated soybean, cottonseed, and jojoba oils represent a promising inexpensive source for fatty acids [59]. There are some cases when amphoteric collectors (e.g., aminopripionic acid [60,61], carboxyethyl imidazoline [62]) are used for floating carbonates. Moreover, nonionic collectors are generally used to improve the performance of ionic surfactants. They reduce the electrostatic repulsions between ionic head groups, generate hydrophobic chain interactions, and consequently, the adsorption of the ionic collector on mineral surfaces [29]. Table 10 presents the conditions and results where anionic and amphoteric collectors are used for the flotation of calcite and dolomite.

According to research conducted on different organic reagents used as dolomite depressants, carboxymethyl cellulose, citric acid, and naphtyl anthyl sulfonates are effective [63]. The $\beta$-naphthyl sulfonate formaldehyde condensate (NSFC) was used as a dolomite depressant during the anionic flotation of collophane at $\mathrm{pH}$ value of 9 [34]. NSFC was chemically adsorbed on the dolomite surface and barely adsorbed to collophane. However, NSFC's chemical toxicity is a severe limitation [34]. Additionally, Bacillus subtilis and Mycobacterium phlei have been tested as depressants of apatite and dolomite [64]. Results indicated the adsorption of both bacteria species on the minerals surfaces. They functioned as depressants for dolomite, as well as for apatite. Although these bacteria do not ensure apatite dolomite selectivity, a simulation of the flotation environment can provide a better choice of bacteria for this purpose.

\section{- Quartz Reagents}

Usually, the elimination of silicates minerals, such as quartz, is conducted using cationic collectors. Table 11 presents different reagents mentioned as silica collectors in the literature. Sodium silicate is reported as a performing quartz depressant. Silva et al. [65] investigated the mechanism of quartz depression using sodium silicate. They have found that at a $\mathrm{pH}$ value of 7 , monomeric $\mathrm{Si}(\mathrm{OH})_{4}$ and polymeric species, resulting of sodium silicate hydrolysis, were adsorbed on the quartz surface. For a sample containing $97.2 \% \mathrm{SiO}_{2}$, the quartz depression was observed at a dosage of $1000 \mathrm{~g} / \mathrm{t}$ $\mathrm{Na}_{2} \mathrm{SiO}_{3}$. Optimum floatability was obtained in the $\mathrm{pH}$ range from 5 to 8 using a dosage of $1500 \mathrm{~g} / \mathrm{t}$ $\mathrm{Na}_{2} \mathrm{SiO}_{3}$ in the presence of $150 \mathrm{~g} / \mathrm{t}$ amine. Under these conditions, quartz floatability was less than $10 \%$. At a pH value of 11 , floatability is high, suggesting that sodium silicate is not adsorbed onto the quartz surface. Morever, starch exhibits a depressive effect on quartz flotation. Its flocculation property enables it to adsorb onto the quartz surface engendering its depression [66]. Nevertheless, starch is not an efficient depressant for quartz due to its low selectivity. It is still used in a number of concentrators as it is cheap in comparison to other effective reagents [67]. 
Table 9. Families of reagents used in phosphate flotation.

\begin{tabular}{|c|c|c|c|c|c|}
\hline & \multicolumn{5}{|c|}{ Selective Phosphate Flotation } \\
\hline \multicolumn{2}{|r|}{ Apatite } & \multicolumn{2}{|c|}{ Calcite and Dolomite } & \multicolumn{2}{|c|}{ Quartz } \\
\hline Collectors & Depressants & Collectors & Depressants & Collectors & Depressants \\
\hline $\begin{array}{c}\text { Anionic } \\
\text { - Fatty acids, } \\
\text { - Hydroxamates } \\
\text { Amphoteric, } \\
\text { Cationic. }\end{array}$ & $\begin{array}{l}\text { • Fluosilicic acid, } \\
\text { • Sulfuric acid, } \\
\text { - Phosphoric acid and its derivatives, } \\
\text { - Natural polysaccharides (Starch), } \\
\text { • Synthetic polymers. }\end{array}$ & $\begin{array}{c}\text { Anionic } \\
\bullet \text { Fatty acids, } \\
\text { - Saponified vegetable oils, } \\
\bullet \text { Ester, } \\
\text { Amphoteric, } \\
\text { Nonionic. }\end{array}$ & $\begin{array}{c}\text { - Natural polysaccharides } \\
\text { (Starch, quebracho), } \\
\text { - Synthetic polymers, } \\
\text { - Inorganic soluble salts, } \\
\text { • Citric acid, } \\
\text { - Hydrofluoric acid. }\end{array}$ & $\begin{array}{c}\text { Cationic } \\
\text { - Amine collectors (Primary, } \\
\text { Secondary, Tertiary amines), } \\
\text { • Amine salts, } \\
\text { - Quaternary ammonium salts. } \\
\text { Amphoteric, } \\
\text { Nonionic. }\end{array}$ & $\begin{array}{l}\text { - Cationically modified polysaccharides, } \\
\bullet \text { Inorganic soluble salts } \\
\text { (Sodium silicate), } \\
\bullet \text { Hydrofluoric acid. }\end{array}$ \\
\hline
\end{tabular}

Table 10. Collectors used for the selective flotation of carbonates (calcite and dolomite).

\begin{tabular}{|c|c|c|c|c|c|c|c|c|c|}
\hline Type & Name & Supplier & Source & $\mathrm{pH}$ & Dosage & IRR (\%) & $\mathrm{P}_{2} \mathrm{O}_{5}$ Increase (\%) & Recovery (\%) & Ref \\
\hline \multirow{5}{*}{ Anionic } & V2711 Flotinor & \multirow[t]{2}{*}{ Clariant } & $\begin{array}{l}\text { Gafsa-Metlaoui Basin; } \\
\text { South of Tunisia. }\end{array}$ & 5 & $0.2 \mathrm{~kg} / \mathrm{t}$ & $69.61 \mathrm{MgO}$ & 11.6 & $92.4 \mathrm{P}_{2} \mathrm{O}_{5}$ & [68] \\
\hline & Flotinor 7466 & & North Africa phosphate ore. & N.A. & $0.6 \mathrm{~kg} / \mathrm{t}$ & $91.13 \mathrm{MgO}$ & 7.76 & $75.1 \mathrm{P}_{2} \mathrm{O}_{5}$ & [69] \\
\hline & Sulfoleic acid (SOA) & $\begin{array}{l}\text { Zhuzhou Chemical Industry } \\
\text { Research Institute }\end{array}$ & $\begin{array}{c}\text { Pure calcite and fluorite } \\
\text { minerals obtained from } \\
\text { Xinyuan Mine, Chenzhou, } \\
\text { Hunan, China. }\end{array}$ & 9 & $6 \mathrm{mg} / \mathrm{L}$ & $80.34 \mathrm{CaO}$ & 7.23 & $85.2 \mathrm{CaO}$ & [70] \\
\hline & $\begin{array}{l}\text { Sodium dodecyl } \\
\text { sulfate (SDS) }\end{array}$ & N.A. & $\begin{array}{l}\text { Yichang, Hubei Province, } \\
\text { China. }\end{array}$ & N.A. & $0.4 \mathrm{~kg} / \mathrm{t}$ & $60.20 \mathrm{MgO}$ & 6.38 & 71.86 & [71] \\
\hline & saponified jojoba oil & Ferquima & $\begin{array}{l}\text { The sedimentary phosphate } \\
\text { deposit of Itataia, Brazil. }\end{array}$ & 6.5 & $200 \mathrm{mg} / \mathrm{L}$ & N.A. & N.A. & N.A. & [72] \\
\hline \multirow[t]{2}{*}{ Amphoteric Collectors } & \multirow[t]{2}{*}{$\begin{array}{l}\text { dodecyl-N-carboxyethyl-N- } \\
\text { hydroxyethyl-imidazoline }\end{array}$} & \multirow{2}{*}{$\begin{array}{l}\text { Lianyungang Chemicals } \\
\text { Plant, Jiangsu } \\
\text { Province, China. }\end{array}$} & $\begin{array}{l}\text { Subbituminous coal } \\
\text { obtained from Peabody } \\
\text { Energy in the USA. }\end{array}$ & N.A. & $0.4 \mathrm{~kg} / \mathrm{t}$ & 95.10 & 8.10 & 88 & \multirow{2}{*}{31} \\
\hline & & & $\begin{array}{l}\text { Phosphate (francolite) from } \\
\text { Quseir (RedSea, Egypt). }\end{array}$ & N.A. & $0.4 \mathrm{~kg} / \mathrm{t}$ & $94.24 \mathrm{MgO}$ & 7.70 & $82 \mathrm{P}_{2} \mathrm{O}_{5}$ & \\
\hline
\end{tabular}

IRR: Impurities-removal-ratio. 
Table 11. Cationic collectors used for the selective flotation of silica (quartz).

\begin{tabular}{|c|c|c|c|c|c|c|c|c|}
\hline Name & Supplier & Source & $\mathrm{pH}$ & Dosage (kg/t) & IRR (\%) & $\mathrm{P}_{2} \mathrm{O}_{5}$ Increase (\%) & Recovery (\%) & Ref \\
\hline Alkyl amine salt (DAH) & \multirow{3}{*}{ N.A. } & \multirow{3}{*}{$\begin{array}{l}\text { The Abyad area } \\
\text { in Jordan. }\end{array}$} & \multirow{3}{*}{5} & \multirow{3}{*}{1} & 66.01 & 5.50 & $85 \mathrm{P}_{2} \mathrm{O}_{5}$ & \multirow{3}{*}{ [73] } \\
\hline $\begin{array}{l}\text { Ether-amine salt } \\
\text { (GE-619) }\end{array}$ & & & & & 48.31 & 4.75 & $80.11 \mathrm{P}_{2} \mathrm{O}_{5}$ & \\
\hline $\begin{array}{c}\text { Quaternary ammonium } \\
\text { salt (CTAB) }\end{array}$ & & & & & 15.54 & 2.67 & $95.45 \mathrm{P}_{2} \mathrm{O}_{5}$ & \\
\hline Flotigam EDA & \multirow{3}{*}{ Clariant, Switzerland. } & \multirow{2}{*}{$\begin{array}{l}\text { Minas Gerais } \\
\text { state, Brazil. }\end{array}$} & 9 & 0.06 & N.A. & N.A. & $100 \mathrm{SiO}_{2}$ & \multirow{2}{*}[74]{} \\
\hline Flotigan 2835-2L & & & 9 & 0.06 & N.A. & N.A. & $87 \mathrm{SiO}_{2}$ & \\
\hline Flotigam 7470 & & $\begin{array}{l}\text { North Africa } \\
\text { phosphate ore. }\end{array}$ & N.A. & 0.42 & 37.14 & 7.76 & $75.1 \mathrm{P}_{2} \mathrm{O}_{5}$ & [69] \\
\hline Lilaflot D817M & \multirow[t]{2}{*}{$\begin{array}{l}\text { AkzoNobel Surface } \\
\text { Chemistry, USA. }\end{array}$} & \multirow{3}{*}{$\begin{array}{l}\text { Peabody Energy } \\
\text { in the USA. }\end{array}$} & \multirow{3}{*}{ Natural } & \multirow{3}{*}{3} & 71.32 & N.A. & $\begin{array}{c}86.75 \\
\text { combustible }\end{array}$ & \multirow{3}{*}{ [70] } \\
\hline Lilaflot 811 & & & & & 65.32 & N.A. & 87.26 combustible & \\
\hline $\begin{array}{l}\text { Dodecyl trimethyl } \\
\text { ammonium bromide } \\
\text { (DTAB) }\end{array}$ & Sigma-Aldrich, USA. & & & & 49.96 & N.A. & 90 combustible & \\
\hline
\end{tabular}




\subsubsection{Apatite Minerals Reagents}

Apatite minerals are usually depressed in acidic medium. Studies showed that at a $\mathrm{pH}$ value below 4.5, apatite floatability is weak due to the dominance of $\mathrm{Ca}^{2+}, \mathrm{CaH}_{2} \mathrm{PO}_{4}{ }^{+}$, and $\mathrm{H}_{2} \mathrm{PO}_{4}{ }^{-}$. The $\mathrm{H}_{2} \mathrm{PO}_{4}{ }^{-}$ species in the suspension occupies apatite's active sites and leads to a poor recovery. Therefore, inorganic acids are considered effective depressants with phosphoric acid being the most used as it does not cause any complication during the enrichment process. Phosphate salts can depress apatite, as well.

Always in acidic medium, using sulfate or oxalate salts is reported to further depress apatite. These reagents incite the precipitation of the dissolved $\mathrm{Ca}^{2+}$, leading to apatite dissolution and a greater presence of phosphate ions in the suspension $[75,76]$.

Additionally, a synthetic polymeric depressant "ACCO-PHOS 950" was developed by Cytec. The aim is to limit apatite loss during silicates flotation using amine collectors. The reagent proved to be effective when used on North Africa's high-grade phosphate ores [77]. Zhang and Snow (2014) [78] investigated sodium tripolyphosphate, fluosilicic acid, diphosphonic acid, starch and sodium silicate as apatite depressants candidates. The phosphate ore used contains $19.82 \% \mathrm{P}_{2} \mathrm{O}_{5}$ and $40.28 \%$ Insol. Sodium tripolyphosphate gave promising results. Using it as apatite depressant yielded a final phosphate concentrate assaying approximately $31 \% \mathrm{P}_{2} \mathrm{O}_{5}$ and up to $7 \%$ Insol with over $94 \% \mathrm{P}_{2} \mathrm{O}_{5}$ recovery. During reverse flotation of silica from a fine-grained feed, starch effectively depressed the apatite.

\subsection{Influence of Particle Size}

Particle size is a main parameter in the flotation process. Particles of various sizes behave differently in the flotation system, directly affecting the recovery, selectivity, and overall performance. Usually, fine particles' flotation is less preferred compared to coarse mineral particles. Fine-grained minerals have a higher surface energy, leading to a nonselective reagent consumption, entrainment or entrapment of particles and an instability of bubble-particle aggregates. A study of the relationship between the phosphate particles size and flotation recovery was carried out by Gaudin et al. (1931). The results revealed that under similar operating conditions, particles of various sizes exhibit different flotation kinetics. The maximum phosphate minerals recovery was obtained when treating size fractions between 60 and $200 \mu \mathrm{m}$. Mineral liberation, which is related to the particle size, is also a parameter in the froth flotation of phosphate ores. Fine grinding is critical to attain greater liberation but will unfavorably affect the separation efficiency. Therefore, there is generally a compromise when choosing the particle size. A preforming flotation system requires an effective liberation of desired minerals without overgrinding the ore.

\subsection{Influence of the Froth Stability}

\subsubsection{Froth Stability}

The attachment of hydrophobic mineral particles to gas bubbles leads to the genesis of a concentrated mineral lather. The froth's stability is critical and is generally maintained using foaming agents (frothers). The froth must sustain the particle's weight, while resisting excessive coalescence and bursting. On the other hand, the proper functioning of the flotation process requires a manageable and easily suppressed froth for a practical recovery [79]. Froth stability is affected by the parameters such as gas flow rate, stirring rate, solid content, particle size, mineralogy, reagents type and dosage, and water's ionic strength. Farrokhpay et al. [80] noted that froth stability can be assessed through parameters such as froth half-life time, froth maximum height at equilibrium, dynamic froth stability factor, bubble growth across the froth phase, air recovery, and solid loading on bubbles on top of the froth surface, froth velocity, and froth rise velocity, etc.

Particle size and solid content: Liu et al. [79] investigated, in their recent study, the effect of particle size and solid content on fluorapatite, calcite, dolomite, and quartz froths stability. Using a setup 
inspired from Lunkenheimer's report [81], they assessed the dynamic froth stability factor $(\Sigma)$ for different particle sizes and solid contents. This factor is calculated using:

$$
\sum=\frac{V_{f}}{Q}=\frac{S \times H_{\max }}{Q}
$$

$V_{f}$ is the froth volume $\left(\mathrm{cm}^{3}\right), Q$ is the gas flowrate $\left(\mathrm{cm}^{3} / \mathrm{s}\right), S$ is the cross-sectional area of the column $\left(\mathrm{cm}^{2}\right)$, and $H_{\max }$ is the maximum froth equilibrium height $(\mathrm{cm})$.

Liu et al. [79] found that for fluorapatite, calcite, dolomite, and quartz the fine particles contribute to froth stability as a result of capillary mechanisms, whilst larger particles lead to froth rapture and instability. Additionally, they observed that increasing the solid content to a certain extent stabilizes the froth (Figure 3).

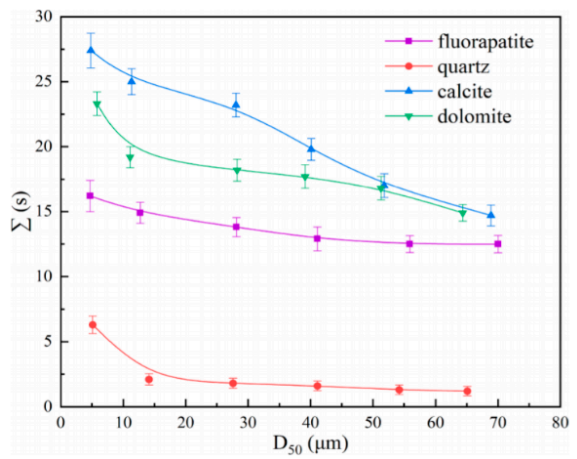

(a)

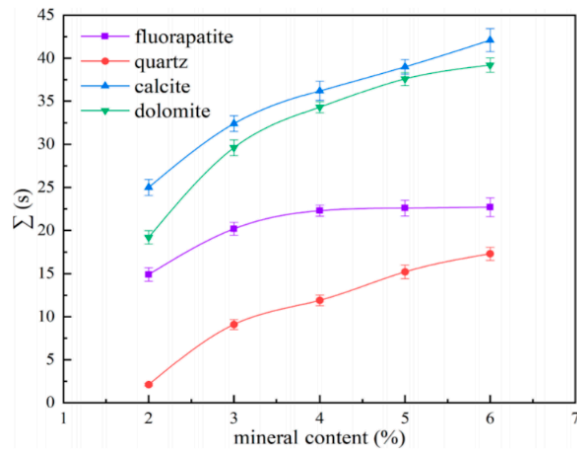

(b)

Figure 3. Effect of (a) particle size (b) solid content of fluorapatite, quartz, calcite, and dolomite on the dynamic froth stability factor [79].

Water's ionic strength/mineralogy: According to Liu et al.'s study [79], dolomite and especially the calcite froths stability were found to be superior than those of fluorapatite and quartz. It was demonstrated that $\mathrm{Ca}^{2+}$ and $\mathrm{Mg}^{2+}$ ions resulting from calcite and dolomite dissolution stabilize the froth. Moreover, the froth half-life time increased dramatically with the addition of $\mathrm{Ca}^{2+}$ ions up to $5.10^{-4} \mathrm{~mol} / \mathrm{L} \mathrm{Ca}^{2+}$ but decreased rapidly thereafter.

Reagent type: The reverse flotation process widely used for upgrading siliceous phosphate ores are considered challenging, especially regarding froth stability. In most cases, cationic collectors are used to float the siliceous gangue. However, they produce an expanding overly stable froth that might entrain other minerals, causing lack of selectivity $[59,79,82]$.

\subsubsection{Bubble's Size}

Hoang et al. [83] studied the effect of flotation time and froth height on the bubble's size. They found that the bubble's size increased with flotation time, contributing to the reagent's consumption and the decrease in the solid content leading to bubble coarsening. They also stated that the bubble's size increased with the froth height due to water film rupture resulting from low reagents concentration and hydrophobic particles existing in the water film.

\section{Conclusions}

Based on common scientific data, it can be deduced that the phosphate ores' enrichment was not as complicated as the enrichment of other minerals, namely, metal sulfides and oxides. The deposits already exploited have been high in $\mathrm{P}_{2} \mathrm{O}_{5}$ content, contained less impurities, and there were not as many strict quality regulations as there is today. With the depletion of these deposits, upgrading complex phosphate ores, while respecting rigorous criteria, is more and more challenging. Phosphate processing 
regulations are not only about the concentrate's quality. They also cover environmental issues, such as $\mathrm{CO}_{2}$ emission, polluting and toxic reagents, water and waste management.

- Huge carbon dioxide emissions are the main downside of thermal beneficiation techniques such as calcination. Hence, froth flotation was developed to replace it in many cases.

- Water recycling is already applied in most phosphate concentrator plants.

- Phosphate waste valorization is an interesting recent topic with numerous industrial opportunities. Hakkou et al. [84] mentioned multiple methods of phosphate wastes valorization. One way is the use of alkaline phosphate wastes (APW) to inhibit the acid mine drainage (AMD). Regarding its high calcite content, $15 \%$ APW was used to neutralize the acidity produced by pyrrhotite tailings' oxidation [85]. The APW were also assessed in the passive AMD water treatment [84]. Additionally, phosphate wastes with a size less than $1 \mathrm{~mm}$, were tested in store-and-release (SR) covers to reclaim industrial mine sites [86].

- Flotation reagents can be environmentally harmful and highly toxic. For instance, different apatite depressants (organic and inorganic) are used in the reverse flotation of sedimentary phosphate ores. The most common ones are phosphoric and sulfuric acid and their derivatives. Using these inorganic depressants can entail, however, potential threats to the environment [87] (e.g., calcium phosphate scale formation and water eutrophication [88]). Organic depressants have been developed for apatite/carbonate separation, as well. Nevertheless, they are usually extremely toxic which limits their use [87].

Author Contributions: Conceptualization, M.D. and YT; methodology, M.D. and Y.T.; validation, Y.T., M.B. and R.H.; writing—original draft preparation, M.D.; writing—review and editing, M.D. and Y.T.; supervision, Y.T, R.H. and M.B.; project administration, Y.T.; funding acquisition, Y.T, R.H. and M.B. All authors have read and agreed to the published version of the manuscript.

Funding: This research was financially supported through the research program between OCP S.A under the specific agreement OCP/UM6P AS34.

Conflicts of Interest: The authors declare no conflict of interest.

\section{References}

1. Langton, T.G. Phosphate rock. In Natural Resources in U.S.-Canadian Relations, Volume 2: Patterns and Trends in Resource Supplies and Policies; Routledge: London, UK, 2019; pp. 123-142. [CrossRef]

2. Haldar, S.K. Mineral Exploration; Elsevier: Amsterdam, The Netherlands, 2018; ISBN 9780128140222.

3. Abouzeid, A.Z.M. Physical and thermal treatment of phosphate ores-An overview. Int. J. Miner. Process. 2008, 85, 59-84. [CrossRef]

4. Jasinski, S.M. U.S. Geological Survey, Mineral Commodity Summaries: Phosphate Rock. Available online: https://www.usgs.gov/media/files/phosphate-rock-mcs-2019-data-sheet (accessed on 9 November 2020).

5. Marcin, E.J. The Formation of Phosphate Minerals and Deposits. Rocks Miner. 1963, 38, 457-459. [CrossRef]

6. Santana, R.C.; Duarte, C.R.; Ataíde, C.H.; Barrozo, M.A.S. Flotation selectivity of phosphate ore: Effects of particle size and reagent concentration. Sep. Sci. Technol. 2011, 46, 1511-1518. [CrossRef]

7. Kawatra, S.K.; Carlson, J.T. Beneficiation of Phosphate Ore; Society for Mining, Metallurgy \& Exploration: Englewood, CO, USA, 2013; ISBN 0873353919.

8. Lisiansky, L.; Baker, M.; Larmour-Ship, K.; Elyash, O. A Tailor Made Approach for the Beneficiation of Phosphate Rock. In Beneficiation of Phosphates; Zhang, P., Miller, J.B., Wingate, E., Filho, L.L., Eds.; Society for Mining, Metallurgy \& Exploration: Englewood, CO, US, 2015.

9. Wang, D. Flotation Reagents: Applied Surface Chemistry on Minerals Flotation and Energy Resources Beneficiation: Volume 1: Functional Principle; Springer: Berlin/Heidelberg, Germany, 2016; Volume 1, ISBN 9789811020308.

10. Aslan, N.; Fidan, R. Optimization of $\mathrm{Pb}$ flotation using statistical technique and quadratic programming. Sep. Purif. Technol. 2008, 62, 160-165. [CrossRef]

11. Barros, L.A.F.; Ferreira, E.E.; Peres, A.E.C. Floatability of apatites and gangue minerals of an igneous phosphate ore. Miner. Eng. 2008, 21, 994-999. [CrossRef] 
12. Bulatovic, S.M. Handbook of Flotation Reagents: Chemistry, Theory and Practice: Flotation of Industrial Minerals; Elsevier: Amsterdam, The Netherlands, 2014; Volume 3.

13. Chernoff, C.B.; Orris, G.J. Data Set of World Phosphate Mines, Deposits, and Occurrences: Part A. Geologic Data; US Department of the Interior, US Geological Survey: Reston, VA, USA, 2002.

14. Al-Fariss, T.F.; Ozbelge, H.O.; El-Shall, H.S. On the Phosphate Rock Beneficiation for the Production of Phosphoric Acid in Saudi Arabia. J. King Saud Univ. Eng. Sci. 1992, 4, 13-31. [CrossRef]

15. Chaabouni, A.; Chtara, C.; Nzihou, A.; Feki, H.E.L. Study the Nature and the Effects of the Impurities of Phosphate Rock in the Plants of Production of Phosphoric Acid. J. Adv. Chem. 2014, 7, 1296-1299. [CrossRef]

16. Mar, S.S.; Okazaki, M. Investigation of Cd contents in several phosphate rocks used for the production of fertilizer. Microchem. J. 2012, 104, 17-21. [CrossRef]

17. Ulrich, A.E. Science of the Total Environment Cadmium governance in Europe's phosphate fertilizers: Not so fast? Sci. Total Environ. 2019, 650, 541-545. [CrossRef]

18. El-Arabi, A.E.-G.M.; Khalifa, I.H. Application of multivariate statistical analyses in the interpretation of geochemical behaviour of uranium in phosphatic rocks in the Red Sea, Nile Valley and Western Desert, Egypt. J. Environ. Radioact. 2002, 61, 169-190. [CrossRef]

19. Wu, L.; Forsling, W.; Schindler, P.W. Surface complexation of calcium minerals in aqueous solution. 1. Surface protonation at fluorapatite-water interfaces. J. Colloid Interface Sci. 1991, 147, 178-185. [CrossRef]

20. Somasundaran, P.; Wang, Y.H.C. Surface Chemical Characteristics and Adsorption Properties of Apatite. Adsorpt. Surf. Chem. Hydroxyapatite 1984, 129-149. [CrossRef]

21. Selvamani, V. Stability studies on nanomaterials used in drugs. In Characterization and Biology of Nanomaterials for Drug Delivery; Elsevier: Amsterdam, The Netherlands, 2019; pp. 425-444.

22. Al Mahrouqi, D.; Vinogradov, J.; Jackson, M.D. Zeta potential of artificial and natural calcite in aqueous solution. Adv. Colloid Interface Sci. 2017, 240, 60-76. [CrossRef] [PubMed]

23. Cao, Q.; Zou, H.; Chen, X.; Wen, S. Flotation selectivity of N-hexadecanoylglycine in the fluorapatite-dolomite system. Miner. Eng. 2019, 131, 353-362. [CrossRef]

24. Wang, L.; Tian, M.; Khoso, S.A.; Hu, Y.; Sun, W.; Gao, Z. Improved Flotation Separation of Apatite from Calcite with Benzohydroxamic Acid Collector. Miner. Process. Extr. Metall. Rev. 2019, 40, 427-436. [CrossRef]

25. Zheng, X.; Arps, P.J.; Smith, R.W. Adsorption of Bacillus subtilis to minerals: Effect on the flotation of dolomite and apatite. In Process Metallurgy; Elsevier: Amsterdam, The Netherlands, 1999; Volume 9, pp. 127-136. ISBN 1572-4409.

26. Han, Y.; Han, S.; Kim, B.; Yang, J.; Choi, J.; Kim, K.; You, K.S.; Kim, H. Flotation separation of quartz from apatite and surface forces in bubble-particle interactions: Role of $\mathrm{pH}$ and cationic amine collector contents. J. Ind. Eng. Chem. 2019, 70, 107-115. [CrossRef]

27. Ruan, Y.; Zhang, Z.; Luo, H.; Xiao, C.; Zhou, F.; Chi, R. Effects of metal ions on the flotation of apatite, dolomite and quartz. Minerals 2018, 8, 141. [CrossRef]

28. Zhou, F.; Liu, Q.; Liu, X.; Li, W.; Feng, J.; Chi, R.A. Surface Electrical Behaviors of Apatite, Dolomite, Quartz, and Phosphate Ore. Front. Mater. 2020, 7, 1-9. [CrossRef]

29. Filippova, I.V.; Filippov, L.O.; Duverger, A.; Severov, V.V. Synergetic effect of a mixture of anionic and nonionic reagents: Ca mineral contrast separation by flotation at neutral pH. Miner. Eng. 2014, 66, 135-144. [CrossRef]

30. Perrone, J.; Fourest, B.; Giffaut, E. Surface characterization of synthetic and mineral carbonate fluoroapatites. J. Colloid Interface Sci. 2002, 249, 441-452. [CrossRef] [PubMed]

31. Abdel Khalek, M.A. Separation of dolomite from phosphate minerals by flotation with a new amphoteric surfactant as collector. Trans. Inst. Min. Metall. Sect. C Miner. Process. Extr. Metall. 2001, 110, 89-93. [CrossRef]

32. Kou, J.; Tao, D.; Xu, G. Fatty acid collectors for phosphate flotation and their adsorption behavior using QCM-D. Int. J. Miner. Process. 2010, 95, 1-9. [CrossRef]

33. Vučinić, D.R.; Radulović, D.S.; Deušić, S.Đ. Electrokinetic properties of hydroxyapatite under flotation conditions. J. Colloid Interface Sci. 2010, 343, 239-245. [CrossRef] [PubMed]

34. Yu, J.; Ge, Y.; Guo, X.; Guo, W. The depression effect and mechanism of NSFC on dolomite in the flotation of phosphate ore. Sep. Purif. Technol. 2016, 161, 88-95. [CrossRef]

35. Yu, J.; Ge, Y.; Guo, W.; Guo, X. Flotation collophane from high-iron phosphate ore by using sodium ligninsulfonate as depressant. Sep. Sci. Technol. 2017, 52, 557-566. [CrossRef] 
36. Li, X.; Zhang, Q.; Hou, B.; Ye, J.; Mao, S.; Li, X. Flotation separation of quartz from collophane using an amine collector and its adsorption mechanisms. Powder Technol. 2017, 318, 224-229. [CrossRef]

37. Karlkvist, T.; Patra, A.; Rao, K.H.; Bordes, R.; Holmberg, K. Flotation selectivity of novel alkyl dicarboxylate reagents for apatite-calcite separation. J. Colloid Interface Sci. 2015, 445, 40-47. [CrossRef]

38. De Oliveira, P.; Mansur, H.; Mansur, A.; Da Silva, G.; Clark Peres, A.E. Apatite flotation using pataua palm tree oil as collector. J. Mater. Res. Technol. 2019, 8, 4612-4619. [CrossRef]

39. Zhou, F.; Wang, L.; Xu, Z.; Liu, Q.; Chi, R. Reactive oily bubble technology for flotation of apatite, dolomite and quartz. Int. J. Miner. Process. 2015, 134, 74-81. [CrossRef]

40. Xu, P.Y.; Li, J.; Hu, C.; Chen, Z.; Ye, H.Q.; Yuan, Z.Q.; Cai, W.J. Surface property variations in flotation performance of calcite particles under different grinding patterns. J. Cent. South Univ. 2018, 25, 1306-1316. [CrossRef]

41. Jiao, F.; Dong, L.; Qin, W.; Liu, W.; Hu, C. Flotation separation of scheelite from calcite using pectin as depressant. Miner. Eng. 2019, 136, 120-128. [CrossRef]

42. Liu, C.; Song, S.; Li, H.; Ai, G. Sulfidization flotation performance of malachite in the presence of calcite. Miner. Eng. 2019, 132, 293-296. [CrossRef]

43. Wang, J.; Zhou, Z.; Gao, Y.; Sun, W.; Hu, Y.; Gao, Z. Reverse flotation separation of fluorite from calcite: A novel reagent scheme. Minerals 2018, 8, 313. [CrossRef]

44. Pokrovsky, O.S.; Schott, J.; Thomas, F. Dolomite surface speciation and reactivity in aquatic systems. Geochim. Cosmochim. Acta 1999, 63, 3133-3143. [CrossRef]

45. Espiritu, E.R.L.; Naseri, S.; Waters, K.E. Surface chemistry and flotation behavior of dolomite, monazite and bastnäsite in the presence of benzohydroxamate, sodium oleate and phosphoric acid ester collectors. Colloids Surfaces A Physicochem. Eng. Asp. 2018, 546, 254-265. [CrossRef]

46. Sun, Z.-X.; Forsling, W. Mineral surface complexation in flotation. In Innovations in Flotation Technology; Springer: Berlin/Heidelberg, Germany, 1992; pp. 263-281.

47. Niu, Y.P.; Sun, C.Y.; Yin, W.Z.; Zhang, X.R.; Xu, H.F.; Zhang, X. Selective flotation separation of andalusite and quartz and its mechanism. Int. J. Miner. Metall. Mater. 2019, 26, 1059-1068. [CrossRef]

48. Yuan, Y.; Lee, T.R. Contact angle and wetting properties. In Surface ScienceTechniques; Springer: Berlin/Heidelberg, Germany, 2013; pp. 3-34.

49. Zheng, X.P.; Smith, R.W.; Misra, M.; Mehta, R.K.; Raichur, A.M. Effect of a water soluble fraction derived from Mycobacterium phlei on the surface characteristics and flotation of apatite and dolomite. Miner. Process. Extr. Metall. Rev. 1998, 19, 355-368. [CrossRef]

50. Xie, J.; Zhang, Q.; Mao, S.; Li, X.; Shen, Z.; Li, L. Anisotropic crystal plane nature and wettability of fluorapatite. Appl. Surf. Sci. 2019, 493, 294-307. [CrossRef]

51. Dong, L.; Wei, Q.; Qin, W.; Jiao, F. Selective adsorption of sodium polyacrylate on calcite surface: Implications for flotation separation of apatite from calcite. Sep. Purif. Technol. 2020, 241, 116415. [CrossRef]

52. Rao, K.H.; Dwari, R.K.; Lu, S.; Vilinska, A.; Somasundaran, P. Mixed anionic/non-ionic collectors in phosphate gangue flotation from magnetite fines. Open Miner. Process. J. 2011, 4, 14-24. [CrossRef]

53. Lu, Y.; Drelich, J.; Miller, J.D. Wetting of francolite and quartz and its significance in the flotation of phosphate rock. Miner. Eng. 1997, 10, 1219-1231. [CrossRef]

54. Wu, Y.; Shuler, P.J.; Blanco, M.; Tang, Y.; Goddard, W.A. An experimental study of wetting behavior and surfactant EOR in carbonates with model compounds. Spe J. 2008, 13, 26-34. [CrossRef]

55. Zhang, H.; Liu, W.; Han, C.; Hao, H. Effects of monohydric alcohols on the flotation of magnesite and dolomite by sodium oleate. J. Mol. Liq. 2018, 249, 1060-1067. [CrossRef]

56. Gence, N. Wetting behavior of magnesite and dolomite surfaces. Appl. Surf. Sci. 2006, 252, 3744-3750. [CrossRef]

57. Yuhua, W.; Jianwei, R. The flotation of quartz from iron minerals with a combined quaternary ammonium salt. Int. J. Miner. Process. 2005, 77, 116-122. [CrossRef]

58. Luo, B.; Zhu, Y.; Sun, C.; Li, Y.; Han, Y. Flotation and adsorption of a new collector $\alpha$-Bromodecanoic acid on quartz surface. Miner. Eng. 2015, 77, 86-92. [CrossRef]

59. Ruan, Y.; He, D.; Chi, R. Review on beneficiation techniques and reagents used for phosphate ores. Minerals 2019, 9, 253. [CrossRef]

60. Clerici, C.; Frisa Morandini, A.; Mancini, A.; Mancini, R. Flotation of a phosphate rock with carbonate-quartz gangue. In Reagents in the Minerals Industry; Springer: Berlin/Heidelberg, Germany, 1984. 
61. Houot, R.; Joussemet, R.; Tracez, J.; Brouard, R. Selective flotation of phosphatic ores having a siliceous and/or a carbonated gangue. Int. J. Miner. Process. 1985, 14, 245-264. [CrossRef]

62. Shao, X.; Jiang, C.L.; Parekh, B.K. Enhanced flotation separation of phosphate and dolomite using a new amphoteric collector. Mining Metall. Explor. 1998, 15, 11-14. [CrossRef]

63. Zheng, X.; Smith, R.W. Dolomite depressants in the flotation of apatite and collophane from dolomite. Miner. Eng. 1997, 10, 537-545. [CrossRef]

64. Zheng, X.; Arps, P.J.; Smith, R.W. Adhesion of two bacteria onto dolomite and apatite: Their effect on dolomite depression in anianic flotation. Int. J. Miner. Process. 2001, 62, 159-172. [CrossRef]

65. Silva, J.P.P.; Baltar, C.A.M.; Gonzaga, R.S.G.; Peres, A.E.C.; Leite, J.Y.P. Identification of sodium silicate species used as flotation depressants. Miner. Metall. Process. 2012, 29, 207-210. [CrossRef]

66. Pavlovic, S.; Brandao, P.R.G. Adsorption of starch, amylose, amylopectin and glucose monomer and their effect on the flotation of hematite and quartz. Miner. Eng. 2003, 16, 1117-1122. [CrossRef]

67. Guimarães, R.C.; Araujo, A.C.; Peres, A.E.C. Reagents in igneous phosphate ores flotation. Miner. Eng. 2005, 18, 199-204. [CrossRef]

68. Boujlel, H.; Daldoul, G.; Tlil, H.; Souissi, R.; Chebbi, N.; Fattah, N.; Souissi, F. The beneficiation processes of low-grade sedimentary phosphates of tozeur-nefta deposit (Gafsa-metlaoui basin: South of Tunisia). Minerals 2019, 9, 2. [CrossRef]

69. Dopico, P.; Lipowsky, G.; Mbonambi, M.; Mahlangu, L.; Makin, B.; Pedain, K.-U.; Silva, W. Phosphate Beneficiation with Novel Collectors for Direct and Reverse Flotation: Beyond Low Cost Fatty Acids; Society for Mining, Metallurgy \& Exploration: Englewood, CO, USA, 2015.

70. Gao, Z.; Gao, Y.; Zhu, Y.; Hu, Y.; Sun, W. Selective flotation of calcite from fluorite: A novel reagent schedule. Minerals 2016, 6, 114. [CrossRef]

71. Sun, K.; Liu, T.; Zhang, Y.; Liu, X.; Wang, B.; Xu, C. Application and mechanism of anionic collector sodium dodecyl sulfate (SDS) in phosphate beneficiation. Minerals 2017, 7, 29. [CrossRef]

72. Santos, E.P.; Dutra, A.J.B.; Oliveira, J.F. The effect of jojoba oil on the surface properties of calcite and apatite aiming at their selective flotation. Int. J. Miner. Process. 2015, 143, 34-38. [CrossRef]

73. Fang, G.; Jun, L. Selective separation of silica from a siliceous-calcareous phosphate rock. Min. Sci. Technol. 2011, 21, 135-139. [CrossRef]

74. Vieira, A.M.; Peres, A.E.C. The effect of amine type, $\mathrm{pH}$, and size range in the flotation of quartz. Miner. Eng. 2007, 20, 1008-1013. [CrossRef]

75. Al-Fariss, T.F.; Arafat, Y.; Abd El-Aleem, F.A.; El-Midany, A.A. Investigating sodium sulphate as a phosphate depressant in acidic media. Sep. Purif. Technol. 2014, 124, 163-169. [CrossRef]

76. El-Mofty, S.E.; El-Midany, A.A. Role of calcium ions and their interaction with depressants in phosphate flotation. Chem. Pap. 2018, 72, 2641-2646. [CrossRef]

77. Cytec Industries Mining Chemicals Handbook; Cytec Industries Inc.: Wayne, NJ, USA, 2002; pp. $103-150$.

78. Zhang, P.; Snow, R.; Song, W.; Ma, X.; Zheng, S. Evaluation of phosphate depressants in the phosphate/dolomite system. In Proceedings of the IMPC 2014-27th The International Mineral Processing Congress, Santiago, Chile, 20-24 October 2014; Volume 26, pp. 101-104.

79. Liu, S.; Ge, Y.; Fang, J.; Yu, J.; Gao, Q. An investigation of froth stability in reverse flotation of collophane. Miner. Eng. 2020, 155, 106446. [CrossRef]

80. Farrokhpay, S. The significance of froth stability in mineral flotation-A review. Adv. Colloid Interface Sci. 2011, 166, 1-7. [CrossRef] [PubMed]

81. Lunkenheimer, K.; Malysa, K. Simple and generally applicable method of determination and evaluation of foam properties. J. Surfactants Deterg. 2003, 6, 69-74. [CrossRef]

82. Ran, J.; Qiu, X.; Hu, Z.; Liu, Q.; Song, B.; Yao, Y. Effect of Clay Slime on the Froth Stability and Flotation Performance of Bastnaesite with Different Particle Sizes 1. Russ. J. Non-Ferr. Met. 2019, 60, 107-117. [CrossRef]

83. Hoang, D.H.; Heitkam, S.; Kupka, N.; Hassanzadeh, A.; Peuker, U.A.; Rudolph, M. Froth properties and entrainment in lab-scale flotation: A case of carbonaceous sedimentary phosphate ore. Chem. Eng. Res. Des. 2019, 142, 100-110. [CrossRef]

84. Hakkou, R.; Benzaazoua, M.; Bussière, B. Valorization of phosphate waste rocks and sludge from the Moroccan phosphate mines: Challenges and perspectives. Procedia Eng. 2016, 138, 110-118. [CrossRef] 
85. Hakkou, R.; Benzaazoua, M.; Bussiere, B. Laboratory evaluation of the use of alkaline phosphate wastes for the control of acidic mine drainage. Mine Water Environ. 2009, 28, 206. [CrossRef]

86. Bossé, B.; Bussiere, B.; Hakkou, R.; Maqsoud, A.; Benzaazoua, M. Assessment of phosphate limestone wastes as a component of a store-and-release cover in a semiarid climate. Mine Water Environ. 2013, 32, 152-167. [CrossRef]

87. Yang, B.; Zhu, Z.; Sun, H.; Yin, W.; Hong, J.; Cao, S.; Tang, Y.; Zhao, C.; Yao, J. Improving flotation separation of apatite from dolomite using PAMS as a novel eco-friendly depressant. Miner. Eng. 2020, 156, 106492. [CrossRef]

88. Jaffer, Y.; Clark, T.A.; Pearce, P.; Parsons, S.A. Potential phosphorus recovery by struvite formation. Water Res. 2002, 36, 1834-1842. [CrossRef]

Publisher's Note: MDPI stays neutral with regard to jurisdictional claims in published maps and institutional affiliations.

(C) 2020 by the authors. Licensee MDPI, Basel, Switzerland. This article is an open access article distributed under the terms and conditions of the Creative Commons Attribution (CC BY) license (http://creativecommons.org/licenses/by/4.0/). 